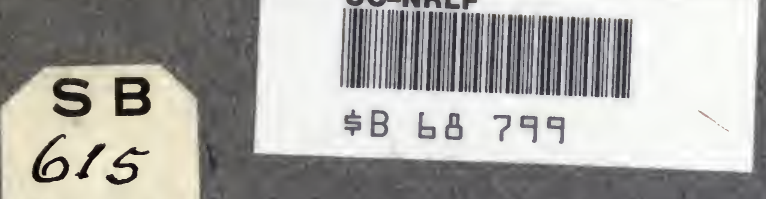

M5F5

THE INARRON-LEAVED IIILINIE WD and

THE BROAD-LEAVED OR SHOWY MILIKYEQT PLAITS POISONOUS TO LIVESTOCK IN AMERICA

By C. E. Fleming and N. F. Peterson

Univ. of Nevada Bul. \#99. December 1920. 


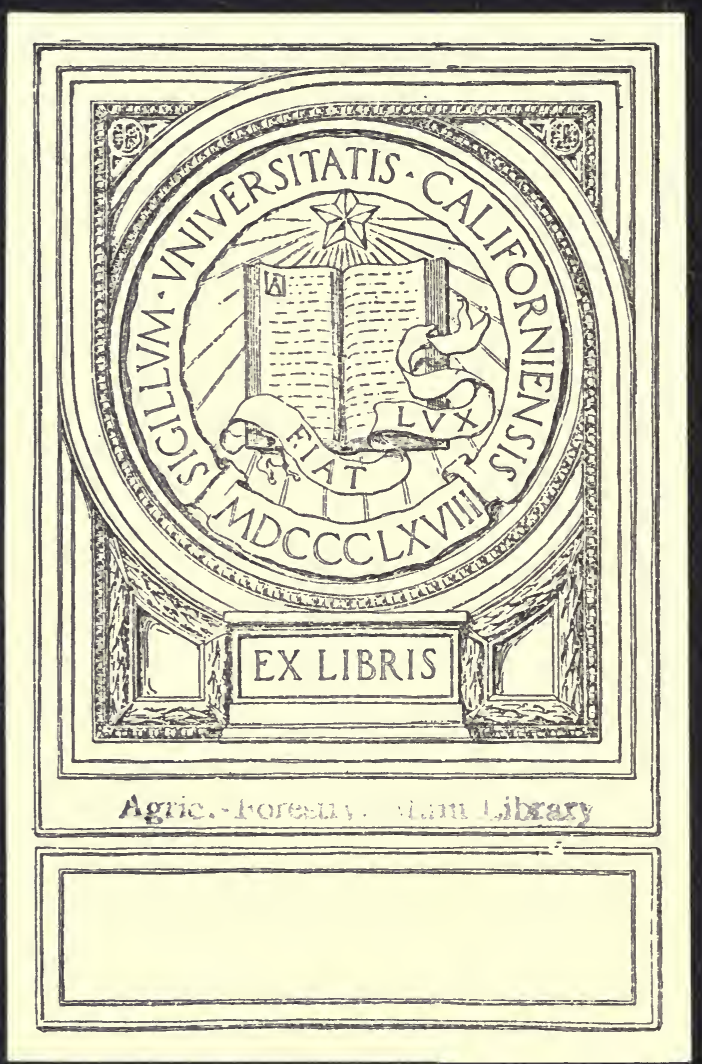




\title{
THE UNIVERSITY OF NEVADA AGRICULTURAL EXPERIMENT STATION
}

\author{
S. B. DOTEN, Director
}

To diminish suffering and loss among domestic animals

\section{THE NARROW-LEAVED MILKWEED}

(Asclepias Mexicana)

and

\section{THE BROAD-LEAVED OR SHOWY MILKWEED}

(Asclepias speciosa)

\section{PLANTS POISONOUS TO LIVE STOCK IN NEVADA}

$$
\text { By }
$$

C. E. FLEMING and N. F. PETERSON

Of the Department of Range Management

Assisted by

M. R. MILLER

Of the Department of Chemistry

and

Dr. L. R. VAWTER and DR. L. H. WRIGHT

Of the Department of Veterinary Science

PUBLISHED BY THE UNIVERSITY OF NEVADA RENO, NEVADA

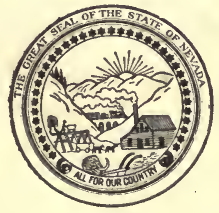

Printed at the

State Printing Office-Joe Farnsworth, Superintendent 

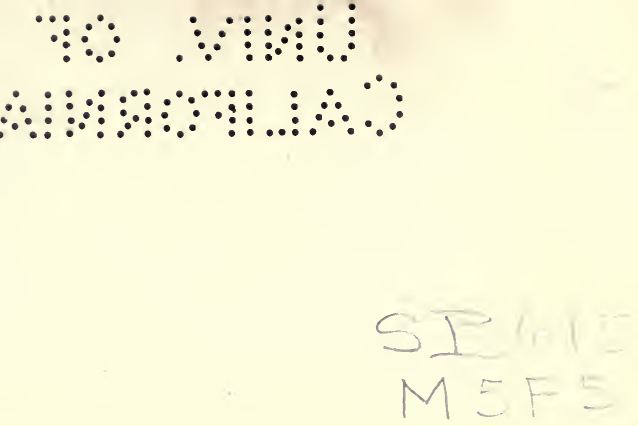

\section{NEVADA AGRICULTURAL EXPERIMENT STATION}

Hon. A. E. Cheney (1921)

BOARD OF CONTROL

Hon. B. F. CURler (1921)

Hon. Walter E. Pratt (1925)

Hon. Mrs. W. H. Hood (1927)

Hon. Miles E. North (1929)

Reno

Elko

Reno

Reno

Reno

\section{OFFICERS}

Walter E. Clark, Ph.D. . . . . . . . . President of University Carolyn BeCKWITH

Charles H. Gorma

etary

Comptroller

\section{STAFF}

Samuel B. Doten, M.A. • . . . . . Director and Entomologist F. L. Bixby, C.E. . . . . . . . . . . Irrigation (In cooperation with Bureau of Public Roads, U. S. D. A.)

Geo. HaRdMan, M.S.

Assistant in Irrigation

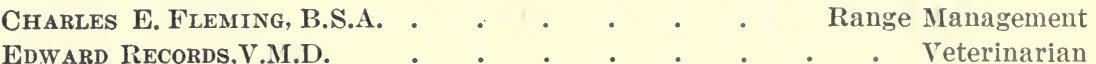
StePhen Lockett,V.M.D. . . . . . . . Assistant Veterinarian

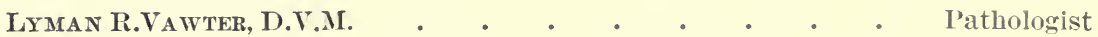
MADGE L. Fink, B.A. . . . @ Secretary to Veterinary Department

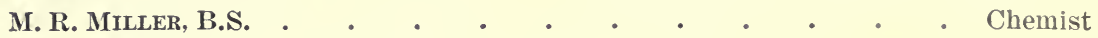
MARTha Rix . . . . . . L Librarian and Secretary to Director 


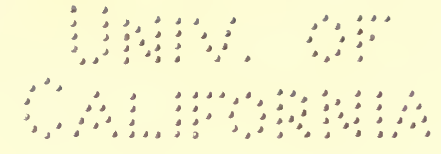

\section{STUDIES OF POISONOUS PLANTS IN THE UNIVERSITY OF NEVADA}

In recent years, as the forage on the open public range in Nevada has become more and more depleted, losses of sheep and cattle from poisonous plants have steadily increased. However, even the stockmen and herders themselves do not know fully just which plants are poisonous nor how to avoid them.

The Nevada Agricultural Experiment Station has therefore undertaken a study of the poisonous plants of the sheep and cattle ranges. The experimental work is of a simple character, consisting largely of practical feeding tests. The plants are brought to the University fresh from the ranges and are fed to common range live stock in small corrals. The symptoms of poisoning are recorded; and after the death of the animal the carcass is cut up and the organs are removed and studied.

An attempt is also made to isolate the active poisonous principle of the plant by suitable chemical methods and to determine its chemical nature.

These experiments are showing clearly which range plants are dangerous, what part of the plant is poisonous, and at what season of the year it must be avoided. They are also showing us that many suspected plants are harmless, while others which are considered harmless are in reality deadly.

In all these experiments it is our purpose first to obtain exact information concerning the poisonous range plants and then to spread it far and wide among the stockmen of the West in the hope of diminishing suffering and loss among western sheep and cattle.

\section{S. B. DOTEN,}

Director, Nevada Agricultural Experiment Station.

November 1, 1920. 
a 


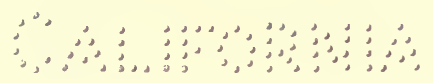

SECTION I

The Milkweeds as Plants Poisonous to Live Stock in Nevada 


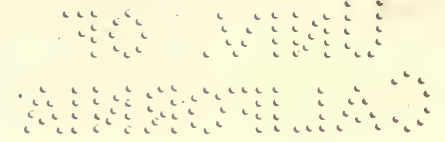




\section{SUMMARY}

(1) There are two common milkweeds in Nevada, both of which are poisonous to sheep and cattle.

(2) One is a slender, erect, branching weed with long, narrow, darkgreen leaves, small flowers, and slender pods. The other is a tall and fleshy weed with large, broad, light-green leaves, coarse flowers, and thick rough pods.

(3) Both kinds grow in fairly moist places, along irrigation ditches, by fences and on stream banks, on roadsides, and in patches in damp pastures.

(4) In the autumn the pods break open and release quantities of flat brown seeds, each of which bears a tuft of shining silky hairs, lighter than thistledown. The seeds are carried far by wind and water. Once established, the plant spreads locally by means of its underground stems.

(5) Animals poisoned by the narrow-leaved milkweed become dull and stupid within a few hours. They walk about with a wobbling, unsteady gait, finally losing all control over the muscles of the legs, and falling or lying down. After the animal is down, it has spasms at short intervals in which the legs are extended rigidly. The heart beats at an increasingly rapid rate; the animal pants and grunts. The head is drawn sharply back. The attack may last for twenty-four hours and end with either the death or the recovery of the animal. If it recovers, it will be in a weak and unsteady condition for several days.

(6) Animals poisoned by the broad-leaved or showy milkweed stop eating, grow dull, and lie down; the breathing is irregular, difficult, and grunting. There are no spasms. The breathing becomes more difficult, and the animals dies quietly.

(7) The narrow-leaved milkweed is far more deadly than the broad. leaved or showy species.

(8) Two or three other milkweeds grow in Nevada; but they are neither common enough nor poisonous enough to be of any importance.

(9) When the narrow-leaved milkweed is accidentally cut and cured in hay, it loses its bad flavor, but keeps its deadly character, thus becoming far more dangerous than when fresh and green. Even the dead and dried leaves, left standing in a field from the summer before, are poisonous in midwinter.

(10) It is a costly and difficult matter to get rid of the narrow-leaved milkweed on even a small piece of ground. If a bit of the underground stem is left in the soil, it will soon produce a new plant.

(11) Both of our poisonous milkweeds have so unpleasant a flavor that neither sheep nor cattle will eat them except when they are very hungry and there is practically nothing else in the field for them to eat.

(12) Poisoning may be prevented by keeping hungry animals and animals in poor condition away from milkweed patches, and by stocking pastures lightly enough to keep the animals constantly provided with other food. 
$\because \vdots \because \quad \vdots \because \vdots \vdots \vdots \vdots \vdots \vdots$

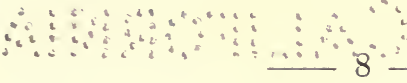

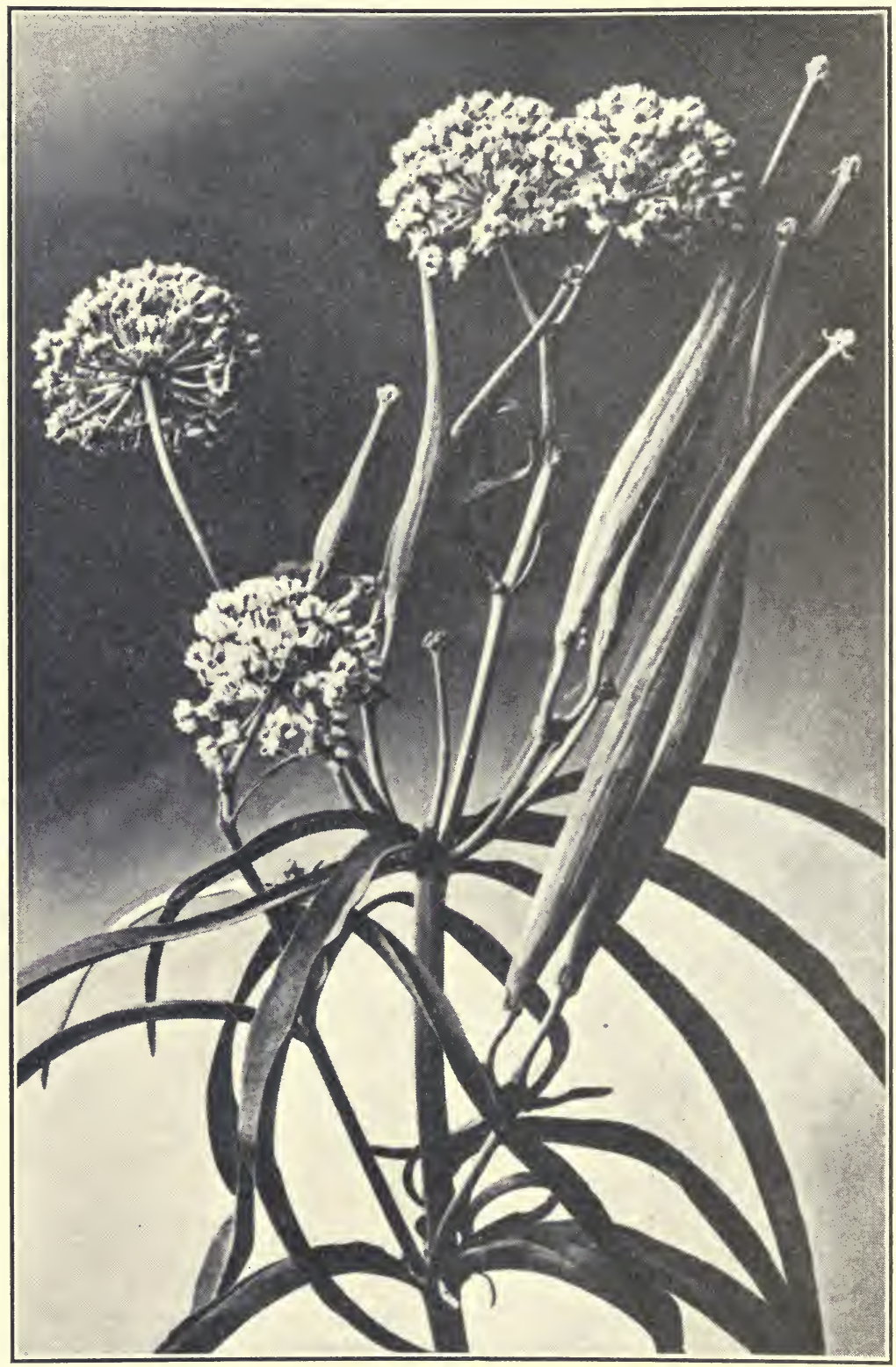

Figure 1-Flowers and Pods of the Narrow-Leaved Milkweed. 


\section{OUR WESTERN MILKWEEDS}

For many years several kinds of milkweed have been looked upon with suspicion or considered poisonous by western stockmen. This opinion was based largely on their own field observations; and little or no experimental work has been done with any of the species except the whorled-leaved milkweed (Asclepias galioides). The latter plant has been carefully studied by the Colorado Experiment Station, which was the first of the western stations to show that sheep may be poisoned by this plant when it is eaten either green or dry. (See Bulletins 246 and 255, Colorado Agricultural Experiment Station.) Later, C. D. Marsh and his associates of the Federal Bureau of Plant Industry published the results of their study of the same species. (See Bulletin No. 800, U. S. Department of Agriculture.)

In the spring of 1918 the attention of the Nevada Experiment Station was first ealled to our local milkweeds as plants dangerous to live stock when several lambs died after eating the tender, juicy young growth of the showy milkweed (Fig. 4). Since that time the Nevada Station has tested the milkweeds by conducting a long series of experiments in which the plants were fed to both sheep and cattle. More work was done with the narrow-leaved milkweed than with any of the others because it seemed to be our most dangerous species. The result of these feeding tests, together with field observations, are presented in this bulletin.

Classes of Live Stock Poisoned and the Extent of Losses in this State and Elsewhere.

Both feeding tests and field observations have shown that the narrowleaved milkweed (Asclepias Mexicana) is poisonous to sheep and cattle. No feedings of any species of milkweed have been made to horses because there seems to be nothing to show that horses have been poisoned by these plants.

Because of the limited time since the milkweeds were recognized as poisonous to live stock in Nevada, the extent of losses cannot be accurately estimated. Further, unless especially large losses take place, they are usually not reported to the Experiment Station. However, because of the widespread distribution of the narrow-leaved milkweed and the ease with which it kills, it is reasonable to assume that losses of live stock, at least in small numbers, are constantly caused by this common poisonous plant.

In other States, notably Colorado, Utah, and New Mexico, it has been proven that the whorled-leaved milkweed has caused the death of many sheep.

\section{Kinds of Milkweed Dangerous to Live Stock in Nevada.}

Several kinds of milkweed grow in Nevada but, from the stockman's point of view, the narrow-leaved species is by far the most important. The other kinds will be discussed briefly toward the end of this bulletin. They are: the Showy Leaved Milkweed (Asclepias speciosa); the Heart-Leaved Milkweed (Asclepias cordifolia) ; and the Prostrate Milkweed (Asclepias cryptoceras). Our experiments seem to show that the heart-leaved and prostrate milkweeds are not poisonous enough or common enough to be dangerous on the range or in pastures in Nevada. 


\section{General Description of the Milkweeds.}

The milkweeds are usually erect plants, little if at all branched, varying in height from one to several feet. The roots live over from year to year, sending up new stems each season. The flowers are lightcolored, white tinged with green or pink; they grow in rounded clusters, each flower stalk arising from the end of the stalk of the cluster.

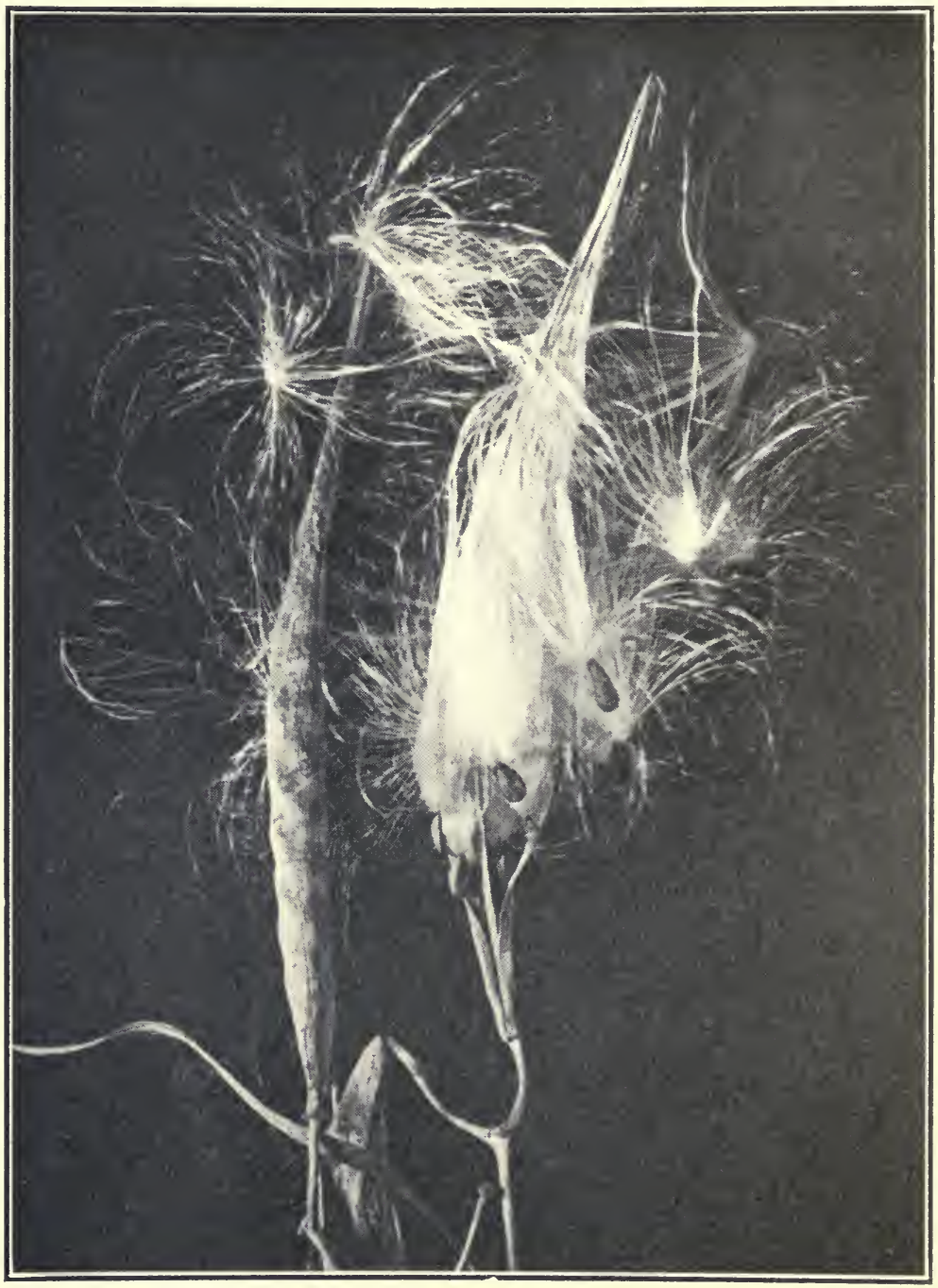

Figure 2-Pods and Seeds of the Narrow-Leaved Milkweed.

Each flower has five cup-like structures (hoods), inside of which there is a horn.

The flowers fall and are followed by seed pods from one to three inches long which open along one side when dry to allow the seeds to escape. The seeds are reddish-brown and flat; on one end there is 
a tuft of long, white, silky hairs by which they are blown about. The roots of the milkweeds are somewhat brittle, whitish and thickened; this is especially true of the showy milkweed (Fig. 4). The growth of the root is mainly horizontal, as is shown in Fig. 5-The Root of the Narrow-Leaved Milkweed. Sometimes, however, the roots penetrate the soil like the roots of alfalfa.

The milkweeds have a milky sap or juice which gives to them their common name and distinguishes them from most other plants. However, a milky sap is found in many other plants, such as the Mexican poppy, the dandelion and its close relatives, the wild lettuce, spurges, and dog-banes. From all these plants having a milky juice, the milkweeds may be distinguished by the following differences: (1) the Mexican poppy is spiny, while the milkweeds are not; (2) the dandelion and its near relatives have no erect stem, while the milkweeds have; (3) the general appearance of the wild lettuce is quite different from the milkweeds and its flower and flower clusters (heads) are like tiny dandelions and not at all like the flower or flower clusters of the milkweed; (4) the spurges (Euphorbia) are mostly low, branching plants with small leaves, the two halves of which are different in shape and size; (5) some of the dog-banes might easily be mistaken for the narrowleaved milkweed, but they branch more freely and tend to be bushy, at least toward the top. Their flowers are not scattered in dense elusters and do not have hoods as in the milkweed. The pods are similar to those of the milkweed but more slender; the seeds are also similar but smaller and not so flattened.

How to Distinguish the Narrow-Leaved Milkweed from the Showy Milkweed.

The showy-leaved milkweed is quite abundant in Nevada, but it is not nearly so poisonous as the milkweed with the long narrow leaves. The two are easily distinguished by the following differences: (1) the narrow-leaved milkweed has several leaves at each joint of the stem, while the shown species has but two; (2) the leaves of the showy milkweed are much broader, from one-third to one-half as broad as they are long; (3) the narrow-leaved milkweed has smooth pods, while the showy species has pods roughened by projections. Figures 3 and 4 show the general appearance and characteristics of these two plants.

\section{Where the Milkweeds Grow.}

The milkweeds are widely distributed in Nevada. They require fairly wet soil, and do not grow on the drier parts of the range. They are common along irrigation ditches and streams, along roadsides, and in pastures and washes and idle lands which have not been cultivated for a number of years. In such locations the narrow-leaved kind is more abundant. It has a wider distribution than the showy milkweed or any of the other species found in this State.

The milkweeds usually grow in full sunlight, although they may be found in partly shaded places as in orchards and among willows and cottonwoods along streams.

In several places in Nevada the narrow-leaved milkweed has been reported to be getting more abundant. Especially is this true along the banks of irrigation ditches. Wherever irrigation systems have been extended to new ground, this poisonous weed soon grows abundantly along the ditch banks. 


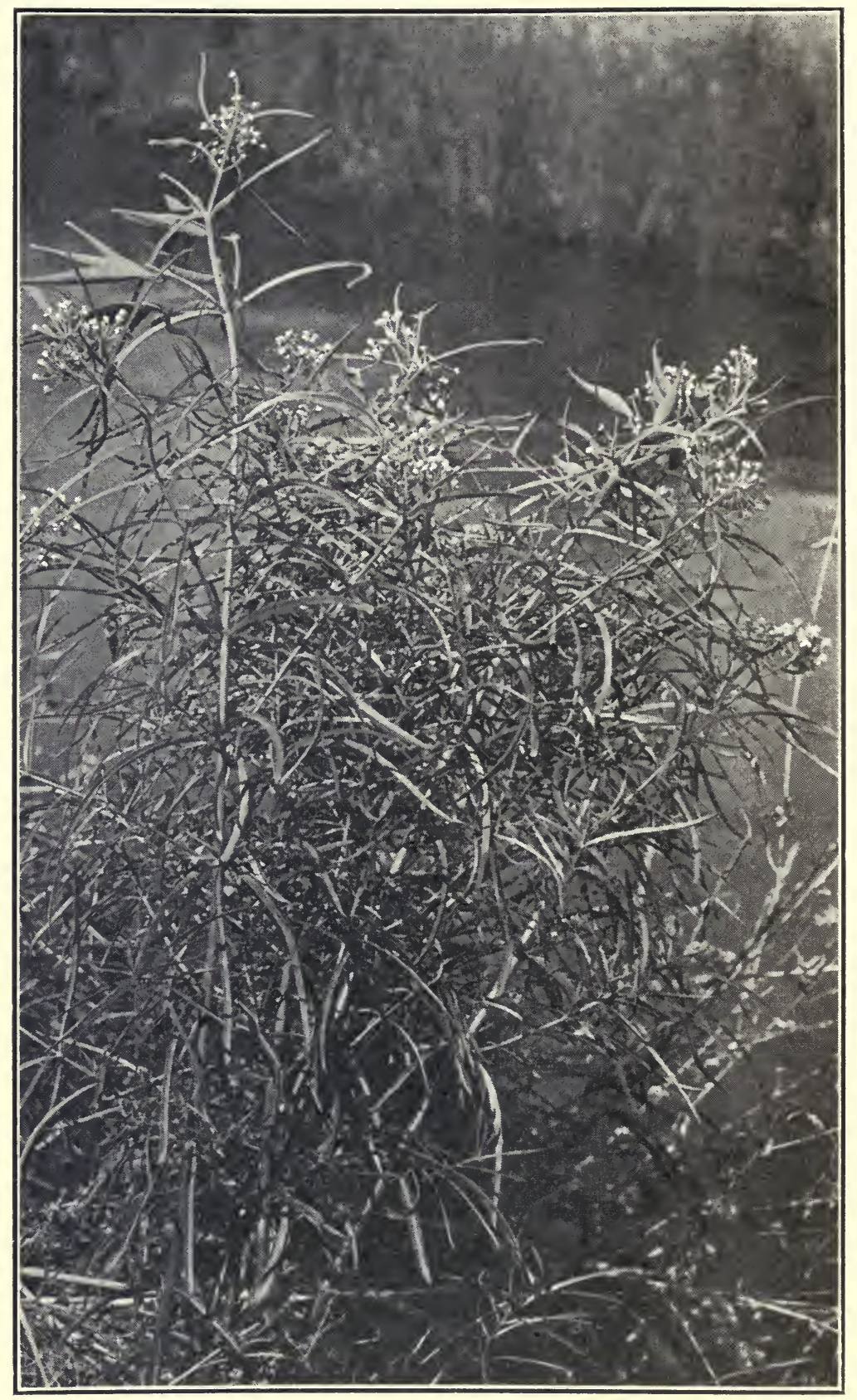

Figure 3-The Narrow-Leaved Milkweed. 


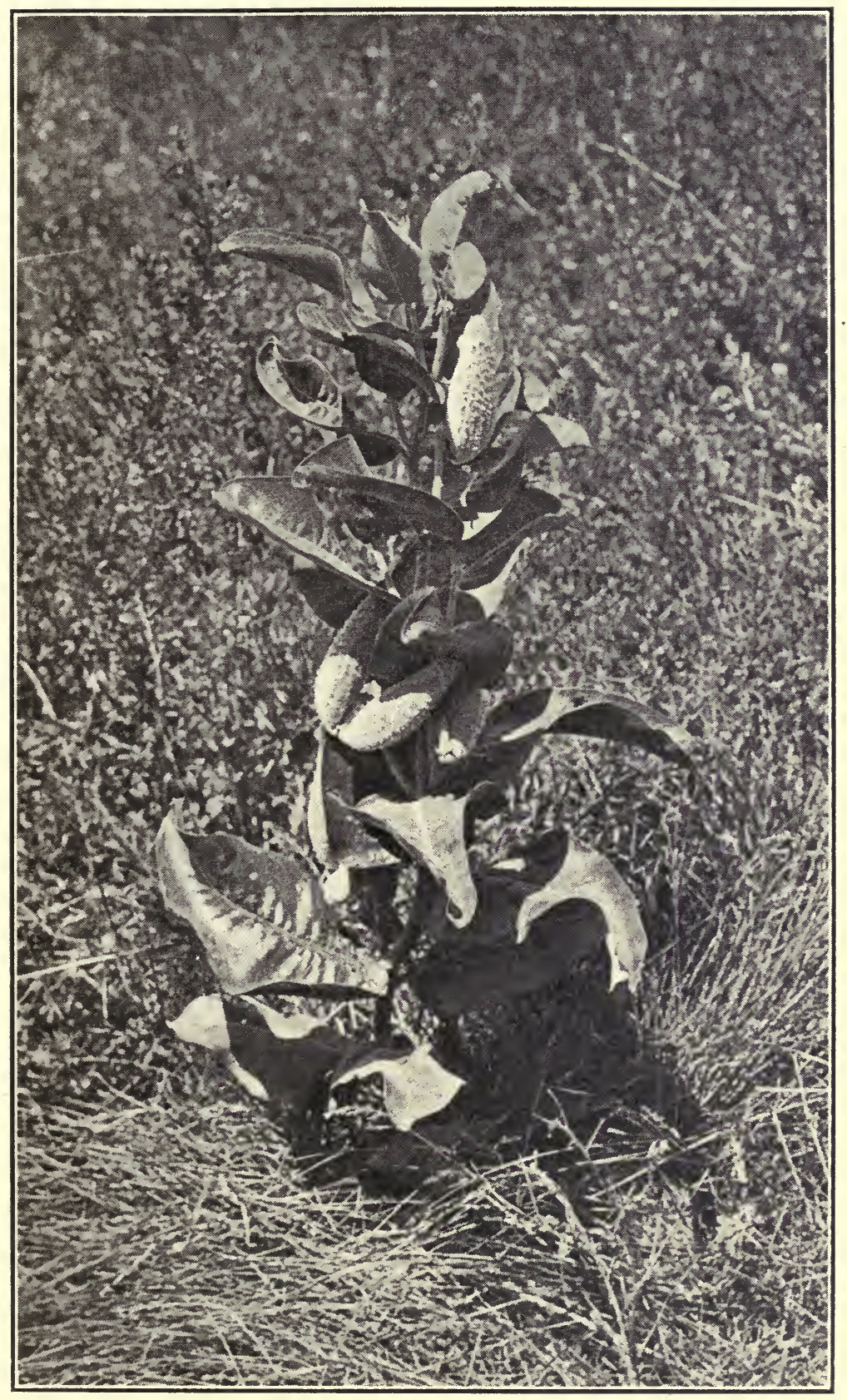

Figure 4-The Broad-Leaved or Showy Milkweed. 
All our observations indicate that after it is once established the narrow-leaved milkweed tends to remain confined to the ditch banks and adjoining moist areas. There seems to be little danger of its establishing itself throughout the alfalfa fields and meadow hay lands to such an extent that it would cause the hay to be discriminated against for feeding purposes.

\section{How the Milkweeds Spread.}

The milkweeds produce quantities of flat brown seeds, each of which bears a tuft of shining silky hair by means of which it floats on the wind and is carried to considerable distances. Often they are blown into irrigation ditches and earried to distant fields by the water.

New patches may start from seeds, or from pieces of roots carried by plows and other farm implements or picked up by the water and transported to new areas.

Where the plant has become established, the size of the patch is usually increased by the shallow horizontal underground stems which give rise to new plants.

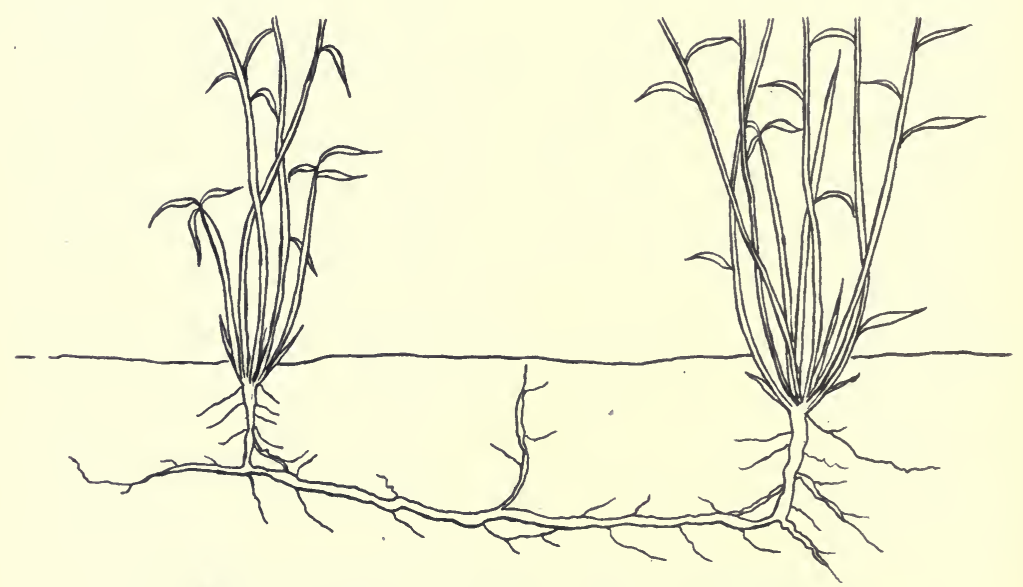

Figure 5-Root of the Narrow-Leaved Milkweed.

It is not uncommon for the same root system to connect up a large number of plants, all of which were produced by the spreading horizontal roots of a mother plant. Thus when it once becomes established it is indeed hard to get rid of this poisonous weed because of the budding of the roots. In some of the milkweeds such buds are known to form as much as two feet below the surface of the ground; and a two-inch piece of the root of the common milkweed was found by A. S. Hitcheock in Kansas to be able to form a new plant. On small areas in Nevada the narrow-leaved milkweed has been dug and pulled two or three times during the season without completely eradicating the plant, because of its ability to produce new plants from small pieces of root left in the soil. Thus any means by which the root is broken up into small pieces and left in the ground will enable the plant to maintain itself and in some instances actually to increase. 


\section{THE NARROW-LEAVED MILKWEED (Asclepias Mexicana)}

The Part of the Plant Which Is Poisonous.

In our experiments we have fed the whole top of the plant, stems, leaves, and sometimes flowers and seed pods. A few feedings were made of leaves only, and these few tests seem to indicate that the leaves are the most poisonous part of the plant. The pods appear to be less poisonous than either the leaves or the stem. Feeding of seeds alone produced no symptoms. This indicates that the plant is not more dangerous, but perhaps less so, when it is full of seed pods than at other times. For all practical purposes the entire plant may be considered poisonous.

\section{The Time of the Year When It Is Poisonous.}

So far as known the narrow-leaved milkweed is poisonous at all stages of growth. Our tests showed it to be poisonous when fed (1) in a green condition, (2) after being cut and dried as hay, and (3) as it dries naturally in the field in the fall. Thus in all stages it is poisonous; and hay containing any large amount of this plant may be regarded as extremely dangerous.

\section{Amount Necessary to Make Sick or to Kill.}

We fed the narrow-leaved milkweed to cattle and sheep, (1) in a fresh green state, (2) after being cut and dried, and (3) as it cured naturally on the stems in the fall, (4) the pods alone, and (5) the seeds alone.

\section{TABLE I}

The Narrow-Leaved Milkweed-The Fresh Green Plant Fed to Sheep

\begin{tabular}{|c|c|c|c|c|c|c|c|}
\hline$\underset{\text { No. }}{\operatorname{nimal}}$ & $\begin{array}{c}\text { Weight } \\
\text { lbs. }\end{array}$ & Date fed & ime fed & & Tim & $\begin{array}{r}\text { Tin } \\
\text { or }\end{array}$ & Final result \\
\hline 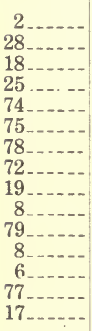 & $\begin{array}{r}120 \\
63 \\
95 \\
93 \\
98 \\
90 \\
87 \\
93 \\
68 \\
72 \\
95 \\
100 \\
65 \\
88 \\
61\end{array}$ & $\begin{array}{l}5-31-18 \\
5-31-18 \\
6-8-18 \\
6-8-18 \\
8-12-20 \\
8-12-20 \\
8-12-20 \\
8-12-20 \\
5-29-18 \\
5-31-18 \\
8-11-20 \\
8-12-20 \\
5-31-18 \\
8-12-20 \\
5-29-18\end{array}$ & $\begin{array}{l}\text { 2:25 p. m. } \\
\text { 2:30 p. m. } \\
\text { 4:00 p. m. } \\
\text { 4:05 p. m. } \\
\text { 4:05 p. m. } \\
\text { 4:10 p. m. } \\
\text { 4:15 p. m. } \\
\text { 4:40 p. m. } \\
\text { 4:10 p. m. } \\
2: 40 \text { p. m. } \\
\text { 4:10 p. m. } \\
\text { 4:20 p. m. } \\
2: 45 \text { p. m. } \\
\text { 4:30 p. m. } \\
\text { 4:10 p. m. }\end{array}$ & $\begin{array}{l}\frac{2}{3} \\
\frac{3}{4} \\
1 \\
1 \\
1 \\
1 \\
1 \\
1 \frac{1}{2} \\
1 \frac{1}{2} \\
2\end{array}$ & \begin{tabular}{l} 
6- $9-7: 15$ a. m. \\
\hdashline $8-13-7: 00$ a. $\mathrm{m}$. \\
$8-13-8: 00$ a. $\mathrm{m}$. \\
$5-30-9: 00$ a. $\mathrm{m}$. \\
$6-1-9: 00$ a. $\mathrm{m}$. \\
$8-12-8: 00$ a. $\mathrm{m}$. \\
$8-13-5: 00$ p. $\mathrm{m}$. \\
$6-1-8: 00$ a. $\mathrm{m}$. \\
$8-13-7: 00$ a. $\mathrm{m}$. \\
$-6: 00$ p. m.
\end{tabular} & 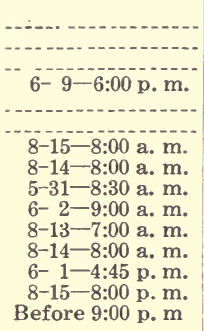 & 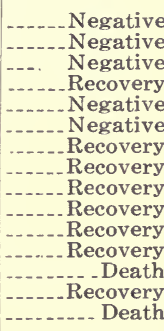 \\
\hline
\end{tabular}

The animals were not watched during the night, usually the first observation being made at 8 o'clock in the morning. This is the reason why, in this and the following tables, under the caption Time of Death or Recovery, "8:00 a. m." appears so often. It records the condition of the animal at the first observation made in the morning.

The tests summarized in this table indicate that $(1)$ if common range ewes eat one-half pound or less no serious trouble will follow; (2) amounts in excess of one-half pound and up to $1 \frac{1}{2}$ pounds will usually make the animal sick, but it will recover; (3) amounts of $1 \frac{1}{2}$ pounds or more are quite likely to eause death. 


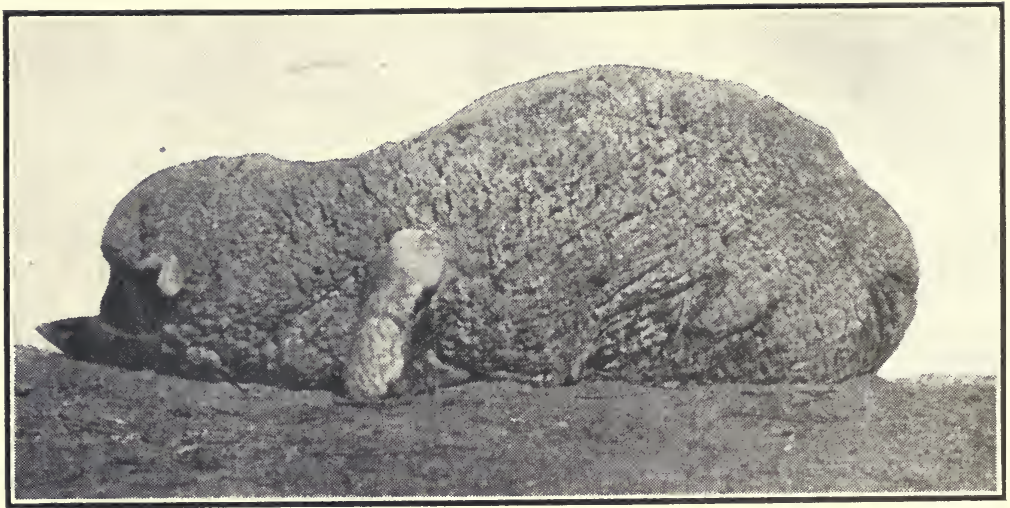

Figure 6-Sheep Poisoned by Narrow-Leaved Milkweed.

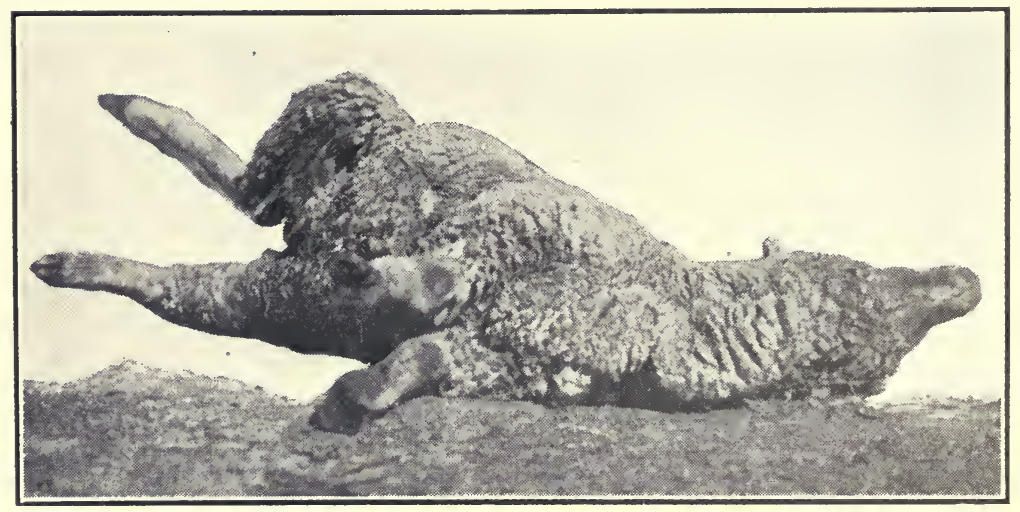

Figure 7-Sheep Poisoned by Narrow-Leaved Milkweed.

TABLE II

The Narrow-Leaved Milkweed-The Air-Dried Plant Fed to Sheep

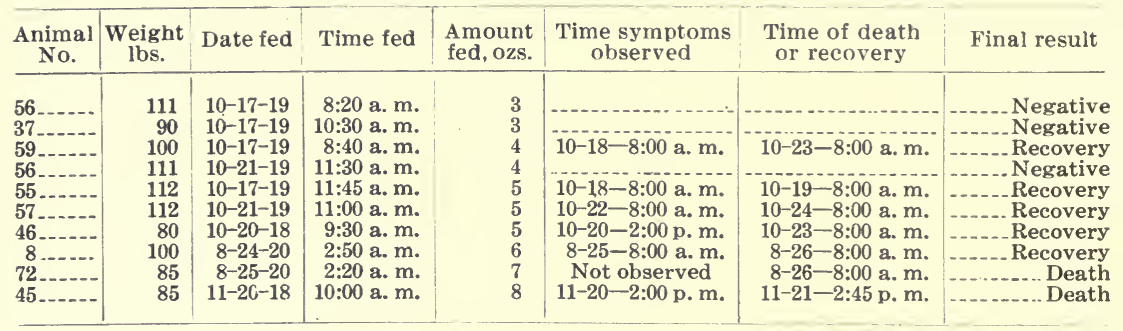

After the green plant has been thoroughly dried in the sun it loses approximately $65 \%$ (two-thirds) of its original weight. Its condition is then much the same as it would be if cut and cured in hay. In the feeding tests the air-dried material was in most instances mixed with alfalfa hay and fed. 
The feedings of hay and milkweed may be briefly summed up for range ewes as follows: (1) 3 ounces may or may not make the animal sick, (2) 4 to 6 ounces will usually produce poisoning, (3) amounts in excess of 6 ounces will probably cause death.

The dried milkweed is evidently very poisonous. While the plant is green sheep are very likely to avoid it because the taste is repellent; but after it is dry it loses much of its bad flavor and is then more dangerous because more readily eaten.

It takes about three parts of fresh milkweed to make one part of air-dried; and it is an interesting fact that if the above amounts of air-dried material are multiplied by 3 to give the original green weight they agree very closely in most cases with the results of Table I.

The feeding tests given in Table II therefore indicate that drying causes little if any loss of the poisonous principle. Consequently when this milkweed is cut and fed in hay, it becomes a serious source of danger.

\section{TABLE III}

The Narrow-Leaved Milkweed-The Plant Which Had Dried Naturally in the Field Fed to Sheep

\begin{tabular}{|c|c|c|c|c|c|c|c|}
\hline $\begin{array}{c}\text { Animal } \\
\text { No. }\end{array}$ & $\begin{array}{c}\text { Weight } \\
\text { lbs. }\end{array}$ & Date fed & Time fed & $\begin{array}{l}\text { Amount } \\
\text { fed, lbs. }\end{array}$ & $\begin{array}{r}\text { Time sym } \\
\text { observe }\end{array}$ & $\begin{array}{l}\text { Time } \\
\text { or re }\end{array}$ & Final result \\
\hline $\begin{array}{l}48 \ldots \ldots \\
58 \ldots \ldots \\
43 \ldots \ldots \\
45 \ldots \ldots \\
43 \ldots \\
43 \ldots \ldots\end{array}$ & $\begin{array}{r}85 \\
115 \\
80 \\
84 \\
80 \\
80\end{array}$ & $\begin{array}{r}11-12-19 \\
11-29-19 \\
12-9-19 \\
12-16-18 \\
12-26-18 \\
1-2-19\end{array}$ & $\begin{array}{l}\text { 2:30 p. m. } \\
\text { 1:50 p. m. } \\
\text { 9:00 a. m. } \\
\text { 10:45 a. m. } \\
11: 30 \text { a. m. } \\
\text { 2:00 p. } \mathrm{m} .\end{array}$ & $\begin{array}{c}3 \\
18 \\
5 \\
16 \\
7 \\
16 \\
\frac{3}{4} \\
1 \\
1 \frac{1}{2}\end{array}$ & $\begin{array}{l}11-30-8: 00 \text { a. } \mathrm{m} \\
12-9-2: 45 \text { p. } \mathrm{m} . \\
12-17-8: 00 \text { a. } \mathrm{m} \\
12-27-8: 00 \text { a. } \mathrm{m} . \\
1-2-9: 00 \text { p. } \mathrm{m} .\end{array}$ & $\begin{array}{l}12-2-8: 00 \text { a. } \mathrm{m} \\
12-10-8: 00 \text { a. } \mathrm{m} \\
12-18-8: 00 \text { a. } \mathrm{m} \\
12-30-8: 00 \text { a. } \mathrm{m} . \\
1-3-3: 00 \text { p. } \mathrm{m} .\end{array}$ & \begin{tabular}{l} 
Negative \\
$\ldots \ldots$ Recovery \\
\hdashline$\ldots$ Recovery \\
\hdashline$\ldots$ Recovery \\
\hdashline$\ldots \ldots$ Recovery
\end{tabular} \\
\hline
\end{tabular}

The plants which were used in the above feeding tests were collected in late autumn after they had fully matured and become dry. The feedings were made in the months of November, December, and January. The results may be summed up briefly as follows: (1) small amounts up to 3 ounces are not dangerous, (2) amounts from 5 to 16 ounces will usually produce poisoning, (3) amounts in excess of 16 ounces are extremely dangerous, and are likely to cause death.

Comparing the results given in Table I with those of Table III, it is found that it takes about as much of the naturally cured material, dry weight, to cause death as of the fresh green plant. From this it appears that some of the poison is destroyed or lost when the dried. plant stands exposed to snow and rain after the leaves are dead.

During the fall and winter months the dried plants may be found still standing. Other feed is usually very short and scarce at that time of the year; and the narrow-leaved milkweed, still retaining a considerable part of its original poison, is then a source of danger to grazing animals.

TABLE IV

The Narrow-Leaved Milkweed-Seeds Fed to Sheep

\begin{tabular}{|c|c|c|c|c|c|c|c|}
\hline$\underset{\text { No. }}{\text { Animal }}$ & $\begin{array}{c}\text { Weight } \\
\text { lbs. }\end{array}$ & Date fed & Time fed & $\begin{array}{l}\text { Amount } \\
\text { fed, ozs. }\end{array}$ & $\begin{array}{c}\text { Time symptoms } \\
\text { observed }\end{array}$ & $\begin{array}{l}\text { Time of death } \\
\text { or recovery }\end{array}$ & Final result \\
\hline $58 \ldots$ & $\begin{array}{r}98 \\
101\end{array}$ & $\begin{array}{l}9-7-19 \\
9-7-19\end{array}$ & $\begin{array}{l}\text { 3:30 p. m. } \\
\text { 3:40 p. m. }\end{array}$ & $\begin{array}{l}2 \\
5\end{array}$ & & & _... Negative \\
\hline
\end{tabular}


In late summer and early fall

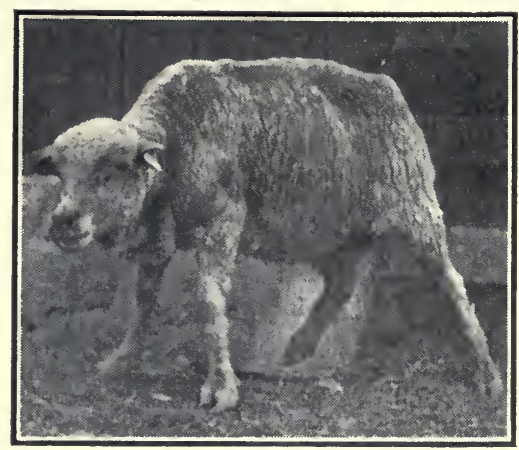

Figure 8-The First Symptoms of Poisoning by Narrow-Leaved Milkweed. slight and that such poisoning is highly improbable.

\section{TABLE V}

The Narrow-Leaved Milkweed-Green Pods Fed to Sheep

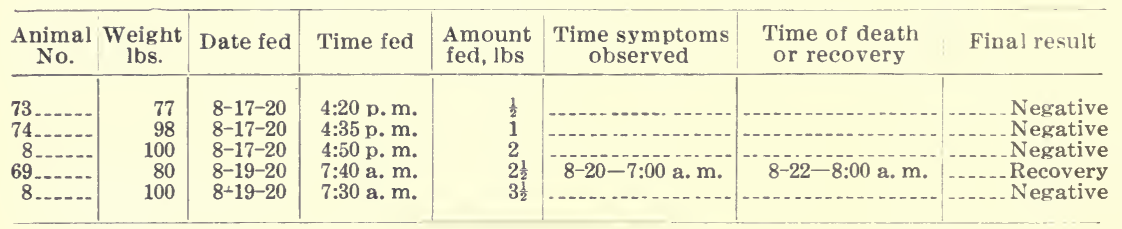

Five feedings of green pods were made, using amounts of from onehalf to $3 \frac{1}{2}$ pounds. None of these feedings caused poisoning with the exception of one $2 \frac{1}{2}$-pound feeding. These tests indicate that the pods are less poisonous than the leaves and stems, and that the danger of loss is smaller when the plant is full of pods.

\section{TABLE VI}

The Narrow-Leaved Milkweed-The Dried Plant Fed on Successive Days to Sheep

\begin{tabular}{|c|c|c|c|c|c|c|c|}
\hline$\underset{\text { No. }}{\operatorname{Animal}}$ & $\begin{array}{c}\text { Weight } \\
\text { lbs. }\end{array}$ & Date fed & Time fed & $\begin{array}{l}\text { Amount } \\
\text { fed, ozs. }\end{array}$ & $\begin{array}{c}\text { Time symptoms } \\
\text { observed }\end{array}$ & $\begin{array}{l}\text { Time of death } \\
\text { or recovery }\end{array}$ & Final result \\
\hline & 85 & $\begin{array}{l}10-21-19 \\
10-22-19 \\
10-23-19 \\
10-24-19 \\
10-25-19 \\
10-26-19 \\
10-27-19 \\
10-28-19 \\
10-29-19 \\
10-31-19\end{array}$ & 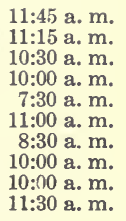 & $\begin{array}{l}2 \\
2 \\
2 \\
2 \\
2 \\
2 \\
2 \\
3 \\
3 \\
4 \\
5\end{array}$ & & 11- $3-8: 00$ a. m. & 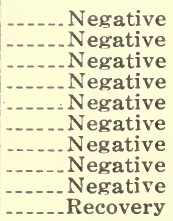 \\
\hline
\end{tabular}

Dry material collected September 6 . Sheep never very sick.

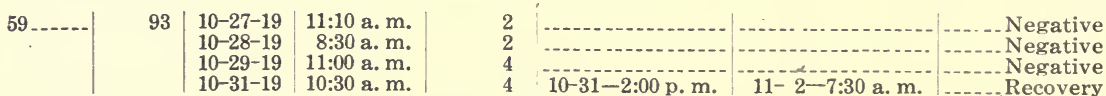

Dry material collected September 6 . Sheep only slightly sick. 
TABLE VI-Continued

\begin{tabular}{|c|c|c|c|c|c|c|c|}
\hline $\begin{array}{l}\text { Animal } \\
\text { No. }\end{array}$ & $\begin{array}{c}\text { Weight } \\
\text { lbs. }\end{array}$ & Date fed & Time fed & $\begin{array}{l}\text { Amount } \\
\text { fed, ozs. }\end{array}$ & $\begin{array}{c}\text { Time symptoms } \\
\text { observed }\end{array}$ & $\begin{array}{l}\text { Time of death } \\
\text { or recovery }\end{array}$ & Final result \\
\hline $59 .$. & 90 & $\begin{array}{l}11-3-19 \\
11-8-19 \\
11-12-19\end{array}$ & $\begin{array}{l}\text { 10:30 a. m. } \\
\text { 11:30 a. m. } \\
\text { 2:00 p. m. }\end{array}$ & $\begin{array}{l}6 \\
7 \\
6\end{array}$ & $\begin{array}{l}11-3-5: 00 \text { p. m. } \\
11-9-7: 00 \text { a. m. } \\
11-15 \text { (dull) }\end{array}$ & $\begin{array}{l}11-6-8: 00 \text { a. } m . \\
11-10-8: 00 \text { a. } m . \\
11-15-8: 00 \text { a.m. }\end{array}$ & \begin{tabular}{l} 
R... Recovery \\
\hdashline Recovery \\
$\ldots$ Recovery
\end{tabular} \\
\hline
\end{tabular}

Material collected as it had dried in the field. Sheep quite sick.

\begin{tabular}{|c|c|c|c|c|c|c|c|}
\hline $\begin{array}{l}10 \mathrm{a} \ldots \\
120 \ldots\end{array}$ & $\begin{array}{r}100 \\
95\end{array}$ & $\begin{array}{l}7-21-19 \\
7-22-19 \\
7-21-19 \\
7-22-19\end{array}$ & $\begin{array}{l}\text { 9:00 a. } \mathrm{m} . \\
\text { 10:25 a. } \mathrm{m} . \\
\text { 9:30 a. } \mathrm{m} . \\
\text { 10:25 a. } \mathrm{m} .\end{array}$ & $\begin{array}{l}2 \\
2 \\
2 \\
2\end{array}$ & $7-22-12 \mathrm{~m}$ & $7-23-10: 00$ a. $\mathrm{m}$. & ....... Negative \\
\hline
\end{tabular}

When animals are poisoned with the narrow-leaved milkweed they are affected for a considerable time, the poison appearing to be eliminated slowly. Because of this slow recovery it was thought that small amounts fed daily might cause an accumulation of the poisonous principle in the animal.

Ewe 37 was fed daily 2 ounces of sun-dried milkweed for six days without showing any symptoms of poisoning. The dose was then increased to 3 ounces for two days. On the following day, 4 ounces were fed without causing any symptoms, and two days later she was fed 5 ounces and became only slightly sick. During the ten-day period she had been fed a total of 27 ounces; yet it was only on the last day, when she was fed 5 ounces, that she showed any signs of poisoning. In all the tests summarized in Table II the feedings of 5 ounces produced symptoms of poisoning. These successive feeding tests of Table VI indicate very clearly that there is little if any cumulative action when the milkweed is fed at brief intervals.

Sheep 59, which had been made very sick with 4 ounces in an earlier experiment, was fed 2 ounces daily for two days; then 4 ounces were fed without producing any symptoms. Two days later, when again fed 4 ounces, this animal was made slightly sick. This feeding test also indicates that there is no cumulative action when small doses are fed on consecutive days.

Three days later, on November 3, Sheep 59, the same animal as mentioned above, was fed 6 ounces of the sun-dried milkweed, which made it quite sick. Five days later it was fed 7 ounces and again it developed symptoms of poisoning. Finally, on November 12, four days later, 7 ounces were fed, the animal again becoming slightly sick. Each of these feedings made the animal sick, but not nearly so sick as the original 4 ounces. The last three feedings were made with a different lot of milkweed material which may have been less poisonous; although when 5 ounces of this lot was fed to another ewe it made her sick for two days.

Animal 10a died when given the second feeding of 2 ounces. This case can hardly be considered as at all typical because the animal was found to have a badly diseased kidney which may have retarded the elimination of the poison and hastened death.

Sheep 120, when fed the same amounts and in a similar way as Sheep 10a, developed no poisoning symptoms and to all outward appearances was normal.

These tests prove rather clearly that there is no cumulative action of the poisonous principle in sheep. The same, it is believed, will hold true for other animals. Rather, they seem to show that there is a 
tendency to develop tolerance for the poison. It may be that the slow recovery is due more to the slowness with which the nervous system recovers from the action of the poison than to the poison being retained in the system.

\section{TABLE VII}

The Nárrow-Leaved Milkweed-The Green Plant Fed to Cattle

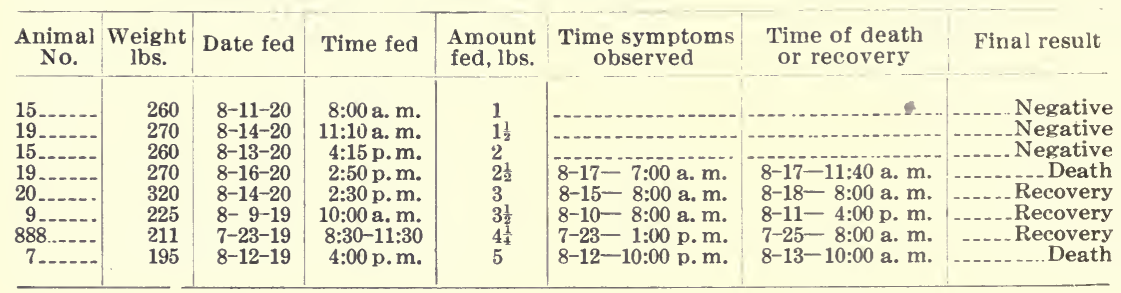

The foregoing table made from tests with yearling animals may be briefly summarized for a stockman's use as follows: (1) amounts below 2 pounds are not ordinarily dangerous; (2) amounts in excess of 2 pounds and up to 5 pounds are dangerous; (3) amounts of 5 pounds or more may be reasonably certain of causing death; (4) there is a wide variation in the susceptibility of individual animals, some being poisoned with less amounts than others.

TABLE VIII

The Narrow-Leaved Milkweed-The Green Pods Fed to Cattle

\begin{tabular}{c|r|c|c|c|c|c|c}
\hline $\begin{array}{c}\text { Animal } \\
\text { No. }\end{array}$ & $\begin{array}{c}\text { Weight } \\
\text { lbs. }\end{array}$ & Date fed & Time fed & $\begin{array}{c}\text { Amount } \\
\text { fed,lbs. }\end{array}$ & $\begin{array}{c}\text { Time symptoms } \\
\text { observed }\end{array}$ & $\begin{array}{c}\text { Time of death } \\
\text { or recovery }\end{array}$ & Final result \\
\hline $15 \ldots \ldots$ & 260 & $8-16-20$ & $1: 45$ p. m. & $2 \frac{1}{2}$ & & & \\
\hline
\end{tabular}

This one feeding showed very clearly from the view-point of a stockman that there is no increased danger from an animal eating pods, for (1) it takes a large number of the plans to produce $2 \frac{1}{2}$ pounds of pods, a greater number than any animal would graze in any one time; and (2) if $2 \frac{1}{2}$ pounds produce no symptoms of poisoning, it is plain that the pods are not especially poisonous.

The following table summarizes the feeding of air-dried narrowleaved milkweed to cattle. This material was cut green and allowed to dry thoroughly in the sun; the weight when dry being approximately $66 \%$ less than the green weight:

TABLE IX

The Narrow-Leaved Milkweed-The Air-Dried Plant Fed to Cattle

\begin{tabular}{|c|c|c|c|c|c|c|c|}
\hline$\underset{\text { No. }}{\operatorname{Animal}}$ & $\begin{array}{c}\text { Weight } \\
\text { lbs. }\end{array} \mid$ & Date fed & Time fed & $\begin{array}{l}\text { Amount } \\
\text { fed, lbs. }\end{array}$ & $\begin{array}{c}\text { Time symptoms } \\
\text { observed }\end{array}$ & $\begin{array}{c}\text { Time of death } \\
\text { or recovery }\end{array}$ & Final result \\
\hline $\begin{array}{r}48 \ldots \\
15 \ldots \ldots \\
49 \ldots \ldots \\
15 \\
8 \ldots \ldots \\
17 \ldots \ldots \\
18 \ldots \ldots \\
31 \ldots \ldots\end{array}$ & $\begin{array}{l}272 \\
260 \\
298 \\
260 \\
225 \\
345 \\
220 \\
280\end{array}$ & $\begin{array}{r}9-24-20 \\
8-25-20 \\
9-15-20 \\
6-15-20 \\
10-16-19 \\
6-16-20 \\
7-21-20 \\
6-14-20\end{array}$ & $\begin{array}{r}10: 00 \text { a. } \mathrm{m} . \\
\text { 1:00 p. } \mathrm{m} . \\
\text { 9:00 a. } \mathrm{m} . \\
\text { 8:00 a. m. } \\
\text { 4-6 p. m. } \\
\text { 10:00 a. m. } \\
\text { 5:00 p. m. } \\
11: 30 \text { a. } \mathrm{m} .\end{array}$ & $\begin{array}{l}\frac{1}{4} \\
\frac{1}{4} \\
\frac{1}{2} \\
\frac{1}{2} \\
\frac{1}{2} \\
\frac{3}{4} \\
\frac{3}{4} \\
\frac{3}{4} \\
3\end{array}$ & $\begin{array}{l}\text { 9-16-4:30 p. m. } \\
6-15-2: 30 \text { p. m. } \\
10-17-8: 00 \text { a. m. } \\
6-17-8: 00 \text { a. m. } \\
7-22-8: 00 \text { a. m. } \\
6-14-7: 00 \text { p. m. }\end{array}$ & $\begin{array}{l}9-17-8: 00 \text { a. m. } \\
6-16-8: 00 \text { a. m. } \\
10-17-11: 00 \text { p. m. } \\
6-18-8: 00 \text { a. m. } \\
7-23-7: 00 \text { a. m. } \\
6-15-7: 00 \text { a. m. }\end{array}$ & \begin{tabular}{|}
$\ldots \ldots$ Negative \\
$\ldots \ldots$ \\
$\ldots \ldots$ \\
$\ldots \ldots$ \\
$\ldots \ldots$
\end{tabular} \\
\hline
\end{tabular}


For the practical purposes of the livestock business the following conclusions may be drawn from this table for yearling animals weighing around 250 pounds: (1) small amounts of one-fourth pound or less are practically harmless; (2) amounts of one-half pound are dangerous but not fatal; (3) amounts of three-fourths of a pound will either kill the animal or make it very sick; (4) all amounts in excess of three-fourths of a pound are highly dangerous.

Animal 31, through a mistake, was fed 3 pounds of the dried plant mixed with alfalfa. The animal ate this very greedily. This shows that an animal will readily eat much more than a fatal dose of the dry milkweed, especially if it is mixed with a.palatable feed such as alfalfa hay. When the plant is dried, it does not lose its poisonous character, but apparently does lose its bad flavor and becomes much more attractive to both sheep and cattle.

\section{SYMPTOMS OF MILKWEED POISONING}

The first symptom noted in sheep is extreme dullness or entire loss of appetite. In as sluggish an animal as a sheep this abnormal dullness is often difficult to detect, and some of the tests recorded as negative may have had this symptom. In several cases there was a distinct trembling over the entire body accompanied by salivation. The next symptom to appear was a wobbly unsteady gait, first noticeable in the hind legs. In several cases this became worse until the animal staggered and was hardly able to walk, sometimes falling over.

In extreme cases this would be followed by a stage where the animal was down and unable to get up. Some of the animals while down were in a comatose stage as if asleep or in deep stupor.

In the fatal cases there was a

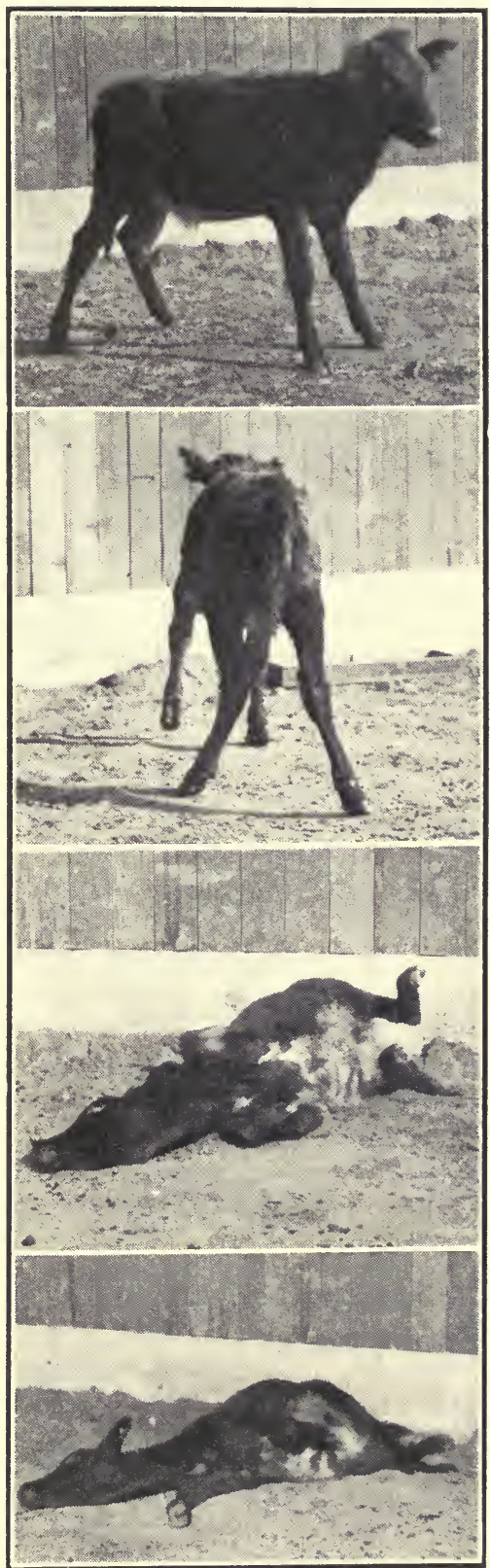

Figure 9-Calf Poisoned by NarrowLeaved Milkweed. series of spasms while the animal was down, much resembling the symptoms of water hemlock (poison parsnip, Cicuta) poisoning. While 
1

in this condition the eyes were staring and bleared, the pupils dilated. The head was drawn far back; in many cases there was champing of the jaws and grating of the teeth, with rapid running or kicking movements of both the hind and front legs, followed by spells when the legs would be extended and rigid. Any disturbance of the animal then brought on additional spasms, attended frequently by bleating grunts or groans. In all fatal cases the spasms occurred at irregular intervals until death, spasms becoming weaker and of shorter duration with a longer interval between them.

In nonfatal cases the symptoms during recovery were as follows: If the animal had been down, it would get up but be hardly able to walk, often falling down in its attempt to keep on its feet. As the animal began to get better it would walk with a distinctly unsteady gait and would sometimes refuse to eat for a considerable length of time. Some would eat while still hardly able to walk. The symptoms would disappear so gradually that it would often be very difficult to say definitely when the animals had recovered, just as it was hard to tell when they began to get sick.

The sheep that died were sick from five to twenty-four hours. Those that recovered were sick from twelve to seventy-two hours, most cases from twelve to forty-eight hours. Cattle showed practically the same series of symptoms as did sheep. Those that died were sick twelve to fifteen hours, and those that recovered were sick eighteen to forty-two hours.

\section{Typical Cases}

Case No. 1-A sheep weighing 100 pounds was fed 4 ounces of airdried leaves at $8: 40 \mathrm{a} . \mathrm{m}$. on November 17,1919 . The following morning at $8 \mathrm{a} . \mathrm{m}$. she was sick and walked with an unsteady gait. At 2 p. m. she was much worse and was hardly able to get up. By 6 o'clock she was down and unable to rise. She lay flat on her side and appeared to be in a deep stupor until $2 \mathrm{p}$. m. of the $20 \mathrm{th}$, when she got up, but walked with a very unsteady gait and appeared to have imperfect. control of the muscles of one hind leg. She was so weak that she fell down, but soon got up again. Next morning she appeared normal, except that she limped on one hind leg.

Case No. $2-$ An ewe weighing 115 pounds was fed 5 ounces of airdried material at 11 a. $\mathrm{m}$. on October 21, 1919. By midnight no symptoms had appeared. At 8 o'clock next morning she was sick and scarcely able to walk. By $11 \mathrm{a} . \mathrm{m}$. she was down and was hardly able to get up. At $9 \mathrm{p}$. m. she was still sick, and the following day she staggered around when she walked. Next morning, October 23, she appeared to have practically recovered.

Case No. 3-A ewe weighing 85 pounds was fed 8 ounces of dry leaves at 10 a. m. on November 20, 1919 . At 2 p. m. she was drooling freely and not eating. By $4: 30 \mathrm{p} . \mathrm{m}$. she walked with an unsteady gait, this being especially noticeable in the hind quarters. She continued to get worse, and at 7:30 p. m. could hardly get up, and when upon her feet could walk only a very few steps before she would fall down. By $9: 30 \mathrm{p} . \mathrm{m}$. she was unable to stand. Next morning at 8 o'clock she was about the same as when seen at $9: 30$ the night before. She made several attempts to get up, but each time would fall over. Over the entire body there was a peculiar trembling of the muscles. At $11 \mathrm{a} . \mathrm{m}$. when- 
ever disturbed or moved she went into convulsions. At 2:30, p. m. she had a severe convulsion, and died at $2: 45 \mathrm{p} . \mathrm{m}$.

Case No. 4-A ewe weighing 65 pounds was fed $1 \frac{1}{2}$ pounds of green material at $2: 45 \mathrm{p}$. m. At $8: 40 \mathrm{p}$. m. she was sick. When she attempted to walk it was with a staggering motion. By 8 o'clock next morning she was down on her side, her head drawn far back, eyes staring and bleared, the pupils dilated. At times she would grind her teeth and champ her jaws. Most of the time there was a rapid running movement of the legs, followed by spells when they would be extended and extremely rigid. This series of movements continued until noon. By 2:30 p. m. the spasms had become weaker and of shorter duration, and the intervals between them were longer. At 3:30 p. m. the spasms were very weak, lasting for an instant or two and recurring about every ten minutes. The animal's temperature was then $105.6^{\circ}$. At 4 p. m. the spasms increased in violence, became more severe and were accompanied by bleating grunts. At 4:15 p. m. there was a severe, spasm lasting about five minutes, accompanied by champing of the jaws, grinding of the teeth, and foaming at the mouth. The head was frequently drawn far back. These severe spasms continued about every two minutes until shortly before death, which occurred at $4: 45$ p. m.

The autopsy showed the spleen slightly mushy, the liver soft and friable; all other organs appeared normal. (Brain not examined.)

Case No. 5-A ewe weighing 80 pounds was fed at 2 p. m. January 2, $1919,1 \frac{1}{2}$ pounds of material that had dried naturally in the field. By 9 a. m. she was sick, walked with an unsteady gait, this being especially noticeable in the hind legs. At $8 \mathrm{a} . \mathrm{m}$. the next day she was down and unable to get up, lying flat on her side with legs stretched out. Frequently she would chew at the bedding, and would champ her jaws most of the time. A peculiar trembling of the nose and lips was noticeable. At $9: 30 \mathrm{p}$. m. she was in the same condition, groaning as if in pain, kicking the hind legs and frothing at the mouth. Her temperature at $1: 30 \mathrm{p} . \mathrm{m}$. was $103^{\circ}$. She was in this condition until.3 p. m., when she died.

Case No. 6-A sheep weighing 100 pounds was fed 2 ounces at 9 a. m. July 21. The next day at 10 a. m. 2 ounces more were fed. By noon the animal was sick, walking with an unsteady gait. It continued to get worse during the afternoon. Next morning it was unable to get up and had convulsions when disturbed. It soon fell over on its side and had running movements with its legs. It remained in this condition until death, which took place about $10 \mathrm{a} . \mathrm{m}$.

The autopsy at $11 \mathrm{a} . \mathrm{m}$. showed the following conditions: There was an acute cloudy swelling of the right kidney. The left was affected by a chronic disease not caused by poisoning. The liver was friable and highly reddened; blood flowed from cut surface. Some of the lymph glands were hemorrhagic. The brain showed marked congestion of the meninges, especially over the cerebellum and the anterior portions of the cerebrum. Many minute pin-point hemorrhages were found in the gray matter of the brain. These were located in the corpus striatum, corpus callosum, medulla, and medullary portions of the cerebrum.

Case No. 7 -A sheep was fed 7 ounces of dry material at 2:30 p. m., 
August 25, 1920. It was found dead next morning at 8 o'clock. The autopsy showed the following: carcass bloated, pupils dilated. There was considerable congestion of the mucous membrane of the fourth stomach (abomasum) and small pin-point hemorrhages in the duodenum. The mucous membrane of the bladder was congested. There was a cloudy swelling of the kidneys. In the brain there was marked congestion of the pia mater, and marked injection of the capillaries of the medulla. Hemorrhages were found in the gray matter of the brain.

Case No. 8-A yearling calf weighing 211 pounds was fed $4 \frac{1}{4}$ pounds of fresh material on July 23, 1919, between 8:30 and 11:30 a. m. At $1 \mathrm{p}$. m. it was frothing at the mouth, and its breathing was rapid and irregular. These symptoms (perhaps not due to the milkweed) soon disappeared and the animal seemed normal the rest of the day. The next morning it walked with a peculiar, stiff staggering gait. It ate a little when fed. At $6 \mathrm{p}$. m. it was very weak and wobbly, much more so than in the morning. At $8 \mathrm{a} . \mathrm{m}$. the next day it was much better, but still walked with a stiff unsteady gait.

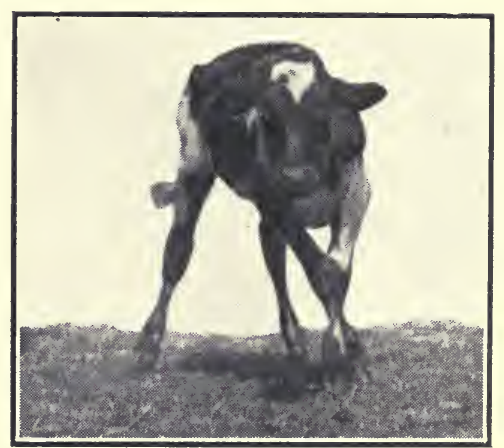

Figure 10-An Early Stage of Poisoning by Narrow-Leaved Milkweed.

Case No. 9 -A yearling calf weighing 225 pounds was fed $3 \frac{1}{2}$ pounds of green material at 10 a. m. on August 9, 1919. At 8 a. m. the next day it was sick and hardly able to get up. When on its feet it was very weak and staggered about. At noon it appeared to be in about the same condition as in the morning. By evening it was much better. Next morning at 8 a. m. it appeared to have quite completely recovered, but at times later in the day it staggered somewhat in walking.

Case No. 10-A yearling calf (195 pounds) was fed 5 pounds of green material at 4 p. m. on August 12, 1919. At 10 p. m. it was slightly sick. Next morning at $80^{\prime}$ clock it was very sick and hardly able to walk, staggering and falling down frequently. Finally it collapsed and lay on its side, kicking rapidly with its legs. Death occurred at 10 a. $\mathrm{m}$.

In the autopsy slight congestion was found in the fourth stomach and in the meninges of the brain.

Case No. 11-A yearling calf weighing 255 pounds was fed on Octo. ber 16,1919 , between 4 and $6 \mathrm{p}$. m., three-fourths of a pound of dry material, which was collected September 6 and air-dried. At 8 a. m. next day it was sick and hardly able to walk. There was marked incoordination of the muscles of the hind legs. At $2 \mathrm{p}$. m. it was down on its side, with legs stretched out, head drawn far back, eyes rolled up; the animal appeared to be dying. This was followed by periods when it seemed to be getting better, but soon it would have another similar attack. During the afternoon it had a series of such attacks. At 8 p. m. it was still down and unable to get up. At midnight it was found 
dead. The autopsy at 9 a. m. October 18 showed slight hemorrhages in the trachea, lungs hemorrhagic, kidneys congested; the heart had severe hemorrhages, both internally and externally.

Case No. 12-A yearling calf weighing 220 pounds was fed threefourths of a pound of dry leaves at 5 p. m. July 21, 1920, which was all eaten next morning. At $8 \mathrm{a}$. $\mathrm{m}$. the animal was sick and walked with an unsteady gait. The incoordination was most marked in the hind legs, especially the left hind leg. The back was curved to the right. It kept getting worse during the afternoon, and was found dead next day at $7 \mathrm{a} . \mathrm{m}$. The autopsy at $9 \mathrm{a}$. $\mathrm{m}$. showed the lymph glands hemorrhagic. There was acute inflammation of the liver and of the bladder. Small hemorrhages were found on the heart. The meninges of the brain were congested in region of the cerebrum. There were minute pin-point hemorrhages in the gray matter of the brain; these were more marked in the left side than in the right. These hemorrhages were located in the corpus striatum and in the medullary portion of the cerebrum and cerebellum.

\section{The Time of the Year When Milkweed Is Poisonous.}

All the feeding tests and field observations clearly indicate that this milkweed is poisonous at all times of the year. Animals have been poisoned and killed by plants collected in the spring of the year when they were just a few inches high, and by plants collected at later stages of growth up to the time when they had become fully matured and dried up in the fall of the year. Losses, therefore, may occur at any time when hungry animals feed upon this milkweed.

\section{Prevention of Losses.}

There is no known remedy for an animal badly poisoned with this plant. Consequently, to avoid losses it is necessary to understand the conditions under which an animal is most likely to eat a fatal dose. The fresh green milkweed as it grows in the field is not relished by any class of live stock and is eaten only under stress of hunger. This is not the case when it is cut and dried and put up in hay, for it then loses a large part of its disagreeable taste and is quite readily eaten. Thus hay containing this milkweed is always dangerous. On the other hand, ranges or pastures where this plant grows are not always dangerous, providing there is enough grass or other forage to satisfy the animals. Thus the losses occur (1) when hungry animals are being herded along driveways or trails where there is little or no feed for stock; (2) when stock are pastured on overgrazed or very closely grazed ranges supporting this plant; (3) when stock are held in pastures growing this milkweed until all the valuable forage has been eaten; and (4) when stock are bedded on areas where this milkweed is abundant.

Most plants of a poisonous nature contain substances which are distinctly distasteful to live stock. In general it may be said that an animal will first graze plants to which it has been used and whose flavor has been found agreeable. However, in the absence of good grazing it will eat what it is forced to eat in an effort to satisfy its hunger. It has been found that on certain ranges many plants are eaten which on other ranges are but seldom touched by the same class of live stock. Further, it has been observed that an animal in good flesh will not, when hungry, eat offensive plants as readily as poor 
hungry animals will. Further, poor half-starved animals are more easily and readily poisoned than when well fed. Thus the condition of the animal determines in a large measure the extent to which it will graze poisonous plants and the probability of serious or fatal poisoning.

\section{THE SHOWY-LEAVED MILKWEED AND OTHERS AS POISONOUS PLANTS}

After two years of observation in the field and in the feeding corrals we have good reason to believe that the narrow-leaved milkweed is of far greater importance as a poisonous plant than any other species of milkweed growing in Nevada. For that reason only a few experiments with the other milkweeds have been made at this Station. The following discussion of the other species found in Nevada will give a general idea of their appearance and poisonous properties:

The Showy Milkweed (Asclepias speciosa).

This species of milkweed can be found in many parts of Nevada, but it does not seem to be very abundant anywhere. It requires about the same conditions for growth as does the narrow-leaved milkweed, and they are often found growing together.

Live stock do not like it, and it is eaten only under stress of hunger. Often fields grazed by cattle may be closely cropped, with this milkweed standing untouched.

As a poisonous plant it seems to be much less important than. the narrow-leaved milkweed. Figure 4 shows the general appearance of this plant growing in the field.

Feeding experiments were made with (1) the green leaves, (2) the leaves as they had dried up naturally in the field, (3) the seeds, and (4) the pods.

TABLE $\mathrm{X}$

The Showy-Leaved Milkweed-Green Leaves, Pods, Seeds, and Dried Leaves Fed to Sheep

\begin{tabular}{|c|c|c|c|c|c|c|c|c|}
\hline 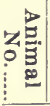 & 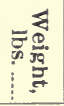 & 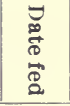 & Time fed & 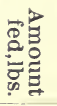 & $\begin{array}{l}\text { Time symptoms } \\
\text { observed }\end{array}$ & $\begin{array}{l}\text { Time of death } \\
\text { or recovery }\end{array}$ & $\begin{array}{l}\text { Final } \\
\text { result }\end{array}$ & $\begin{array}{l}\text { Part of plant } \\
\text { fed }\end{array}$ \\
\hline $\begin{array}{r}42 . \\
84 . \\
64 . \\
100 . . \\
24 . \\
33 . \\
27 . \\
46 . \\
46 .\end{array}$ & $\begin{array}{r}106 \\
103 \\
99 \\
102 \\
85 \\
94 \\
81 \\
80 \\
80\end{array}$ & $\begin{array}{r}9-10 \\
9-11 \\
9-12 \\
9-14 \\
9-6 \\
9-6 \\
9-12 \\
12-16 \\
12-28\end{array}$ & $\begin{array}{r}10: 00 \text { a. } \mathrm{m} . \\
9: 00 \text { a. } \mathrm{m} . \\
10: 00 \text { a. } \mathrm{m} . \\
2: 00 \text { p. } \mathrm{m} . \\
2: 30 \text { p. } \mathrm{m} . \\
11: 30 \text { a. } \mathrm{m} . \\
\text { 4:00 p. } \mathrm{m} . \\
11: 30 \text { a. } \mathrm{m} . \\
10: 00 \text { a. } \mathrm{m} .\end{array}$ & $\begin{array}{l}1 \\
1 \frac{1}{2} \\
2 \\
2 \\
2 \frac{1}{4} \\
24 \\
\frac{1}{2} \\
\frac{1}{2} \\
1^{\frac{1}{2}}\end{array}$ & $\begin{array}{l}9-7-8: 00 \text { a. m. } \\
9-6-6: 00 \text { p. m. } \\
9-7-7: 00 \text { p. m. }\end{array}$ & $\begin{array}{r}\text { 9-10-8:00 a. m. } \\
\text { 7- 7-8:00 a. m. } \\
\text { Before 10:00 p. m. }\end{array}$ & $\begin{array}{l}\text { Negative. } \\
\text { Negative.. } \\
\text { Negative. } \\
\text { Negative.. } \\
\text { Recovery.. } \\
\text { Death.... } \\
\text { Death } \\
\text { Negative. } \\
\text { Negative. }\end{array}$ & \begin{tabular}{l}
-- Green leaves \\
-- Green leaves \\
-- Green leaves \\
-- Green leaves \\
- Green leaves \\
\hdashline$\left\{\begin{array}{l}\text { Geaves dried } \\
\text { in the field }\end{array}\right.$
\end{tabular} \\
\hline
\end{tabular}

The above feedings seem to show that (1) the green leaves are poisonous, (2) relatively large amounts are required to cause poisonous symptoms in a mature range ewe, (3) the pods alone are poisonous, $(4)$ the seeds are highly poisonous, and (5) the plant dried naturally in the field contains little of its original poisonous matter.

Lambs have been fatally poisoned by grazing upon the tender growth 
of this plant in the early spring months when all feed was scarce, but the recorded losses have not been large.

\section{Symptoms of Poisoning by the Showy Milkweed.}

The symptoms of poisoning were quite different from those produced by the narrow-leaved milkweed. The first symptom noted was extreme dullness, with a total loss of appetite and a tendency to lie down. In the severe cases the breathing was distinctly irregular, the breath being expelled with a grunt. Spasms were entirely absent and in the whole series symptoms seemed much unlike those produced by the narrow-leaved milkweed.

\section{Typical Cases}

Case No. 1-On September 6, 1918, at 2 p. m. a yearling range lamb weighing 85 pounds was fed $2 \frac{1}{4}$ pounds of the fresh green leaves. At $8 \mathrm{a} . \mathrm{m}$. the next day it showed symptoms of poisoning. During the day of September 9 it was still sick. September 10 it appeared to have recovered.

Case No. 2-September 6, 1918, at 11:30 a. m. a ewe weighing 94 pounds was fed $2 \frac{1}{4}$ pounds of green pods. She was sick by $6 \mathrm{p}$. m. the same day. At 9:30 she was down; the breathing was labored and grunting. No other symptoms were exhibited. The next morning at 8 a. m. she was found dead.

Case No. 3-September 12, 1918, at 4 p. m. a yearling lamb weighing 81 pounds was fed one-half pound of seeds. At $7 \mathrm{p}$. m. of the same day it was extremely dull, respiration irregular. At 8:30 p. m. it was much worse; the breathing was more labored and each breath was made with a peculiar grunt. At $10 \mathrm{p} . \mathrm{m}$. the animal was dead.

\section{Heart-Leaved Milkweed (Asclepias cordifolia).}

This plant is not abundantly distributed in the fields or ranges of Nevada. It occurs only in the mountain valleys, and does not appear to be poisonous.

Five feedings of this milkweed were made to sheep, the amounts fed ranging from one-half pound to $2 \frac{3}{4}$ pounds. None of the feedings so far as could be observed had any poisonous effect upon the animal.

This milkweed can be distinguished from the showy milkweed by its surface being smooth or free from hairs, while the showy milkweed is covered with fine hairs. The base of the leaf is heart-shaped, which is not the case with the showy milkweed. There is little danger of confusing it with the narrow-leaved milkweed.

\section{Prostrate Milkweed (Asclepias cryptoceras).}

This species of milkweed is not important as a poisonous plant. It grows sparingly and is not widely distributed. It is a plant with somewhat tough leathery leaves, and its growth habit tends to be close to the ground. It may be disregarded as a poisonous plant of any importance in Nevada. One feeding of 3 pounds at one time was made to a mature sheep which did not seem to be at all injured by this large amount. 



\section{SECTION II}

Technical Information Concerning the Narrow-Leaved Milkweed

This section is not intended for use by farmers and stockmen:

The facts included are for the information of chemists and veterinarians. 


\section{SYMPTOMS}

The appearance of symptoms of poisoning in sheep by Asclepias Mexicana occurred about five to seven hours after artificial or natural feeding of the leaves or whole plant.

Five ounces of the dried plant appeared to be the minimum quantity producing symptoms of poisoning in sheep. Three pounds of the dried leaves appeared to be the minimum quantity producing toxic symptoms in a 250-pound calf, with subsequent recovery.

The first noticeable symptoms in either cattle or sheep are general depression, refusal to eat, and unsteady wobbly gait. The unsteady gait is due to partial paralysis of the hind limbs. Occasionally the paralysis is confined to only one limb. This causes an incoordination in movement, and the animal sways from side to side. Marked muscular trembling is sometimes observed, and in a few hours the animal lies down, refusing to arise. During the period of recumbency tetanic spasms (rigid extension) of the limbs occur at intervals of two or three minutes.

There is no perceptible elevation of temperature. The pulse rate increases with the duration of the attack and shortly before death may attain the rate of 180 per minute, becoming very thready. Breathing is labored and rapid. The head is extended backward and quite rigid. The attack may persist for twenty-four hours, and immediately before death the animal lies in a semicomatose state. In case affected animals recover, the gait is unsteady for two or three days. In some cases incoordinate movements of the hind limbs persist as long as one week after the other symptoms have disappeared.

\section{POST-MORTEM LESIONS}

These are not especially characteristic.

Summarizing the observations of post-mortem lesions in sheep and cattle, the following pathological changes were fairly constant in deaths due to ingestion of Asclepias Mexicana:

The liver exhibited passive congestion and low-grade cloudy swelling. Kidneys light in color with low-grade cloudy swelling. The mucosa of the abomasum may exhibit congestion of a moderate degree which may be continuous throughout the small intestine. Occasionally marked arborization of the blood-vessels of small intestines is observed.

Occasional subepicardial petechial hemorrhages are observed along the coronary vessels and auriculo-ventricular border. The heart muscle is pale and friable.

The pia mater in cerebral and cerebellar regions exhibited a marked congestion on cut surfaces; minute capillary hemorrhages were observed in the medullary portion of the cerebrum and cerebellum, also in the cropus striatum. The lateral ventricles contained a moderate amount of sero-sanguinous fluid.

Histopathological examination of selected tissues confirmed the observations made at the autopsy. In the brain the hemorrhages were largely from the minute capillary vessels. Occasional interstitial capillary hemorrhages were observed in the reticular tissue between the convolutions of the cerebrum. 
The liver exhibited acute parenchymatous hepatitis with passive congestion. The kidneys exhibited low-grade parenchymatous nephritis. Myocardium, acute myositis.

\section{THE ACTIVE PRINCIPLE OF ASCLEPIAS MEXICANA}

Several species of Asclepias which are physiologically active have been examined chemically, and, from the work done by various experimenters on those investigated, the compounds to which the physiologieal activity of the plant may be ascribed apparently varies considerably. Glucosides have been found in several species, which act on the animal organism as an emetic. In another species (syriaca) a crystalline resinous substance was found which acted as an anodyne and eathartic. Quackenbush reports finding a crystalline glucoside in Asclepias tuberosa and Asclepias cornuti. March, Clawson, Couch, and Eggleston (U.S. D. A., Bul. 800) have recently reported preliminary experiments on Asclepias galioides, a species closely related to A. Mexicana, in which they found evidence of the presence of toxic compounds having narcotic properties and also those producing a spasmodic type of intoxication. The active principles were not isolated, but experiments on small animals indicated the presence of toxic material in successive extracts of the dry plant, and gave some idea of the solubility relations of these materials. They found that petroleum ether removed no active material, but that benzol extracted substances which were toxic and prodiced effects in test animals similar to those observed in poisoning of sheep by the plant. Ether and chloroform extracts from the material already treated with benzol and petroleum ether also were toxic, indieating the possible presence of more than one active principle. Other solvents failed to remove toxic matter from the residue. Evidence of the presence of a minute quantity of alkaloids was obtained; volatile poisons and saponins were not found. Alcohol alone was found to extract all of the toxic material, a part of which was soluble in water producing narcosis, and the part insoluble in water producing poisoning with symptoms typical of range poisoning.

A portion of the material used in our feeding experiments was examined, and results were obtained which were in some ways similar to those reported on Asclepias galioides.

A small quantity of the plant was extracted successively with solvents and the amounts extracted by each were as follows:

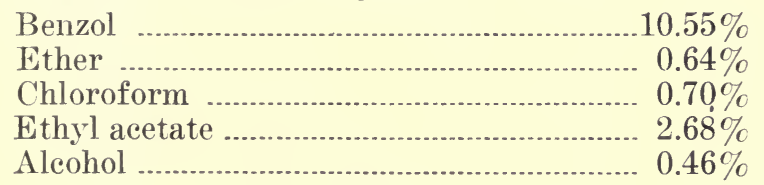

Each of the residues from these extractions were administered to guinea pigs by mouth in amounts corresponding in each case to five grams of the dry plant, and all appeared to be nontoxic, except the benzol extract. Thus benzol is capable of removing all of the toxic substances. No reactions were noted in the cases of the materials extracted by the other solvents, the animals appearing normal.

Another small portion of the dry powder was studied by extracting with dilute acid and testing with the general alkaloidal reagents. With each reagent used, indication was obtained of the presence of alka- 
loids. No alkaloidal preparations were made for animal experiments A larger portion of the plant which had been dried was extracted with alcohol by percolation. 'The alcohol was then removed, and the remaining sirup was evaporated to dryness and extracted repeatedly with boiling water. The aqueous extract so obtained was clear and of a dark-brown color. It had a very sweet taste with a slightly bitte after-taste. The residue from this extraction was a black resinou mass.

The aqueous extract and black residue were administered to a guines pig by mouth. The amounts given corresponded to 5 grams of th dried plant in each case. The aqueous extract proved to be nontoxic the animal remaining normal, but the black residue was fatal in thre hours. The symptoms exhibited by this animal were the same as thos shown by the one to which was given the benzol extract. Apparently then, the active material of Asclepias Mexicana differs from that foun in Asclepias galioides by Marsh, Clawson, Couch, and Eggleston in that the substance producing narcosis found by them in Asclepia galioides is lacking in this plant. It is possible, however, that wit doses representing larger quantities of the plant the narcotic effec might be present and more noticeable.

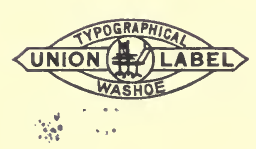


RETURN TO the circulation desk of any University of California Library

or to the

NORTHERN REGIONAL LIBRARY FACILITY Bldg. 400, Richmond Field Station University of California Richmond, CA 94804-4698

ALL BOOKS MAY BE RECALLED AFTER 7 DAYS 2-month loans may be renewed by calling (510) 642-6753

1-year loans may be recharged by bringing books to NRLF

Renewals and recharges may be made 4 days prior to due date

\section{DUE AS STAMPED BELOW}

NOV 24 TYY2

Returned by

NoV 111992

inta Crese simen 
